\title{
Experimental continuously reinforced concrete pavement parameterization using nondestructive methods
}

\section{Parametrização de pista experimental de pavimento de concreto continuamente armado através de método não destrutivo}

L. SALLES a lucio.salles@usp.br

J. T. BALBO a jotbalbo@usp.br

\begin{abstract}
Four continuously reinforced concrete pavement (CRCP) sections were built at the University of São Paulo campus in order to analyze the pavement performance in a tropical environment. The sections short length coupled with particular project aspects made the experimental CRCP cracking be different from the traditional CRCP one. After three years of construction, a series of nondestructive testing were performed - Falling Weight Deflectometer (FWD) loadings - to verify and to parameterize the pavement structural condition based on two main properties: the elasticity modulus of concrete $(E)$ and the modulus of subgrade reaction $(k)$. These properties estimation was obtained through the matching process between real and EverFE simulated basins with the load at the slab center, between two consecutive cracks. The backcalculation results show that the lack of anchorage at the sections end decreases the $E$ and $k$ values and that the longitudinal reinforcement percentage provides additional stiffness to the pavement. Additionally, FWD loadings tangential to the cracks allowed the load transfer efficiency (LTE) estimation determination across cracks. The LTE resulted in values above $90 \%$ for all cracks.
\end{abstract}

Keywords: concrete pavement, consitnuous reinforcement, deflections, backcalculation, load transfer efficiency.

\section{Resumo}

Quatro seções experimentais de pavimento de concreto continuamente armado (PCCA) foram construídas no campus da Universidade de São Paulo com a finalidade de analisar o desempenho deste tipo de pavimento em clima tropical. A curta extensão das seções aliada a aspectos específicos de projeto fizeram com que o PCCA experimental apresentasse um padrão de fissuração bastante distinto dos PCCA tradicionais. Passados três anos da construção, realizou-se uma série de testes não destrutivos - aplicações de Falling Weight Deflectometer (FWD) - para verificar e parametrizar a condição estrutural do pavimento com base em dois fatores principais: o módulo de elasticidade do concreto (E) e o módulo de reação do subleito $(\mathrm{k})$. A estimativa das propriedades foi obtida através da equiparação de bacias reais com bacias simuladas pelo programa EverFE para a carga aplicada no meio da placa formada por duas fissuras. Os resultados da retroanálise mostram que a falta de ancoragem no final das placas diminui os valores de $\mathrm{E}$ e $\mathrm{k}$ e que a porcentagem de armadura proporciona um adicional de rigidez ao pavimento. Adicionalmente, aplicações de carga tangenciais às fissuras possibilitaram a determinação da eficiência de transferência de carga (LTE) entre fissuras. A LTE resultou em valores acima de $90 \%$ para todas as fissuras.

Palavras-chave: pavimento de concreto, armadura contínua, deflexões, retroanálise, eficiência de transferência de carga. 


\section{Introduction}

Over the past 20 years, the evaluation of pavements by Falling Weight Deflectometer (FWD) became the main non-destructive analysis method of operational pavements. Factors such as no need for material removal (destruction) and relatively user-friendly equipment explain the success of this methodology [1]. The determination of pavement properties through backcalculation algorithms based on deflection measurements has also become a routine operation in the study and evaluation of road structures. However, one should perform a very careful process both in the choice of the backcalculation method and in the equalization of real (field) and theoretical deflection basins. Warns have been issued of disastrous parameterization results if failures occur in the backcalculation process [2]

For concrete pavements, a study compared the three most common models used for backcalculation models based on finite element, and concluded that the logarithm based on the "infinite slab" presents more accurate results than the "single slab" one. The "nineslab" model presents correlation values between the real and the theoretical deflections very similar to those of the "infinite slab", although the former process has a much more complex methodology than the latter. Therefore, the authors' recommendation for general studies is the use of "infinite slab" model because of its easier applicability and that the of "nine-slab" model should only be performed for specific cases that require a more detailed approach [3].

The work described here presents the entire backcalculation process of an experimental continuously reinforced concrete pavement $(\mathrm{CRCP})$ in order to parameterize the four sections and to estimate the elastic modulus of concrete $(E)$ and modulus of subgrade reaction $(k)$. The relation of these parameters with very specific aspects of this pavement type is discussed. For the backcalculation, a finite element model with nine slabs called EverFE was used. Additionally, the deflection analysis made it possible to calculate the load transfer efficiency (LTE) across cracks for all the cracks in the pavement. The LTE affects the performance of both jointedplain concrete pavements (JPCP) and CRCP; and can be a good indicator of early structural problems on the slab that could lead to future failures [4]. In JPCP, a low LTE can lead to excessive spalling on the transverse joints and the development of longitudinal cracks; in the CRCP, LTEs below $70 \%$ are routinely found on slabs with punchouts failures [5].

\subsection{Short experimental CRCP}

The CRCP is a concrete pavement without contraction joints: a

\section{Figure 1 - CRCP versus JPCP}

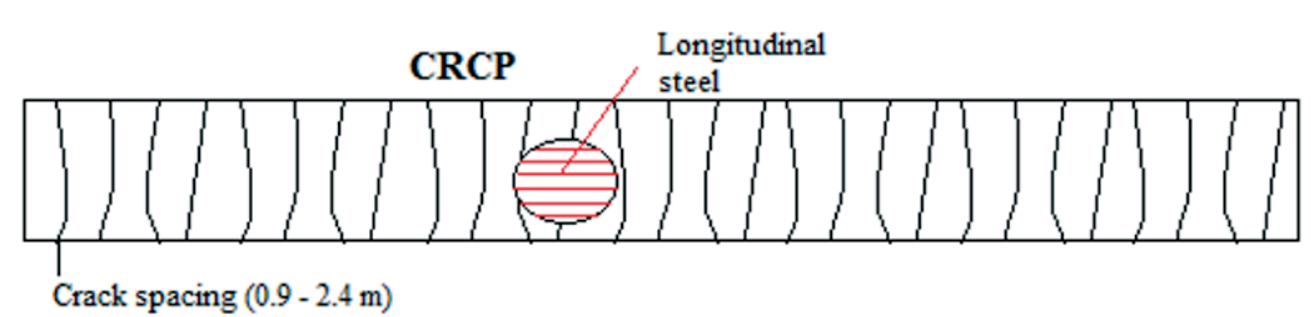

Crack spacing $(0.9-2.4 \mathrm{~m})$

JPCP

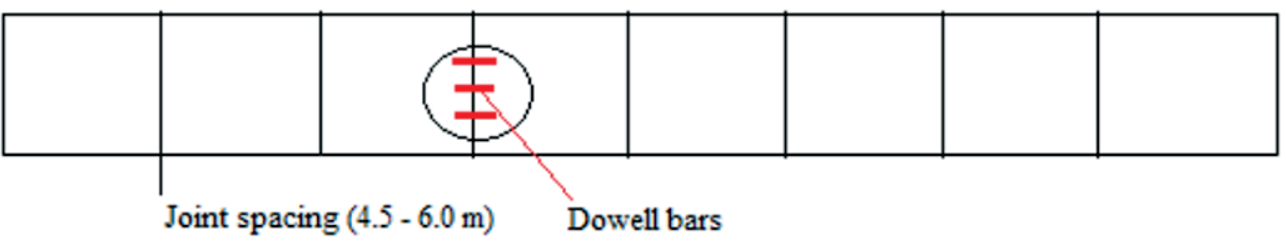

Longitudinal steel

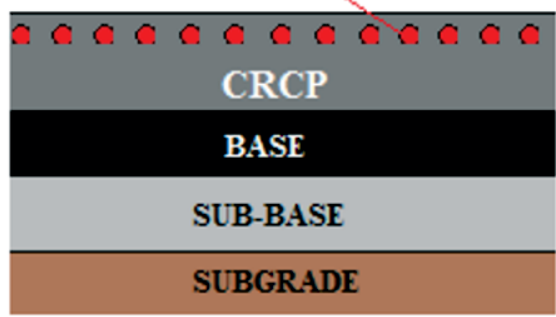

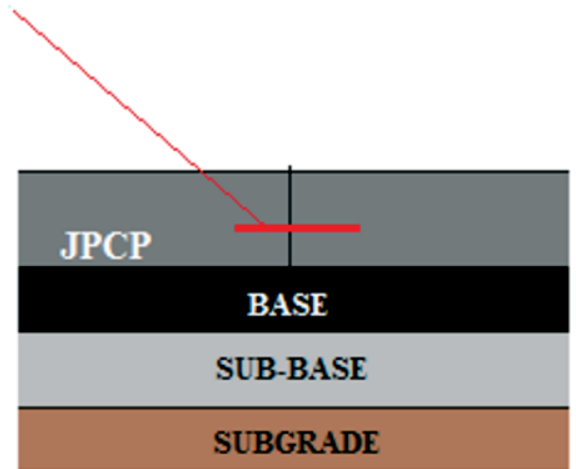




\section{Figure 2 - FWD test position for LTE measurement}

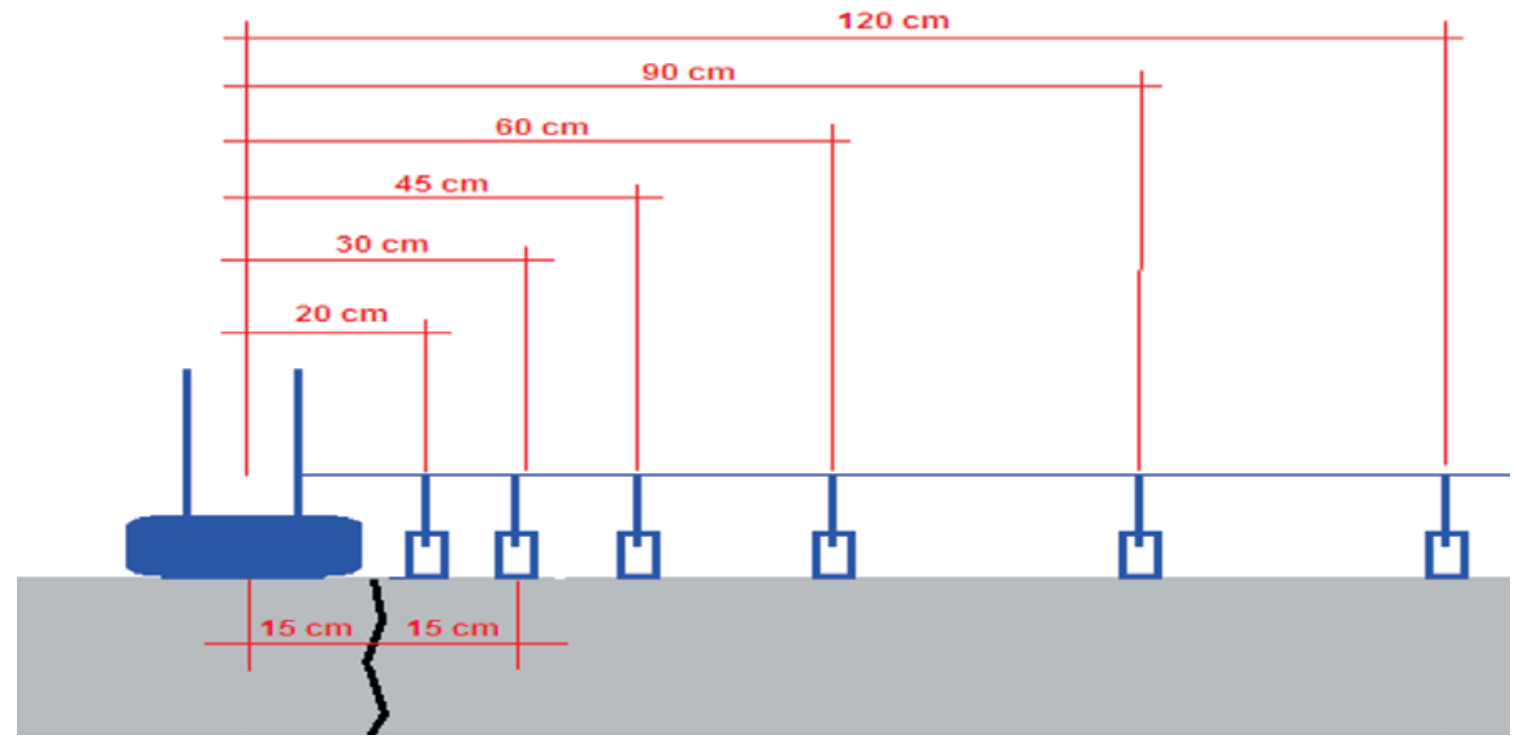

continuous slab with only a constructive joint when the concrete pouring stops. The major difference from JPCP is the presence of a high reinforcement ratio slightly above the slab neutral axis whose sole purpose is to keep the inevitable cracks, caused by the concrete shrinkage, strongly tight. As a result of this tightening action, the cracks are imperceptible to the user and load transfer efficiency is highly satisfactory due to aggregate interlocking. Thus, there is not a cracking control or induction as it is in JPCP, because there is a whole steel structure designed to maintain the slab structural and functional integrity once the random cracking begins [6]. Figure 1 shows the basic differences between the traditional CRCP and JPCP.

In 2010, an experimental CRCP was built at the USP campus in São Paulo. The idea was to evaluate the slab behavior under a tropical climate, as well as to develop a new technology for bus corridors and stops in Brazil. To simulate a bus stop, the experimental CRCP sections are only $50 \mathrm{~m}$ in length and $5.05 \mathrm{~m}$ wide, a short length in relation to traditional CRCP with more than $300 \mathrm{~m}$ in length between constructive joints. Also, there was no anchorage system at the end of the slabs; the sections were free to move during the concrete curing. Those differences impacted the short CRCP crack behavior; there were less cracks than expected and, therefore, a greater crack spacing [7]. The study of dynamic deformations with different operating speeds showed stresses below the concrete strength, indicating a good structural performance of the slab [8]. The design of the short CRCP was a $240 \mathrm{~mm}$ thick concrete slab over a $60 \mathrm{~mm}$ asphalt concrete base over a $300 \mathrm{~mm}$ dry macadam sub-base. The only difference between the sections was the amount of longitudinal steel: section 1 has $0.6 \%$, section 2 , $0.7 \%$, section $3,0.5 \%$ and finally section 4 with less steel at $0.4 \%$; more details and construction aspects can be found elsewhere [9]

\section{Falling Weight Deflectometer (FWD) test methodology}

To determine the LTE across cracks, the simplest and most routinely applied method is the one introduced by Shahin in 1985 [10], in which the load transfer percentage is determined by the relation between the symmetrical deflections at the loaded slab (ס1) and at the unloaded slab (ס2). For this, the FWD plate must be positioned tangentially to the crack so that at least two sensors are equally distanced from the slab, one at the loaded slab and the other at the unloaded slab. The calculation is performed by Equation 1.

$$
L T E=\frac{\delta_{2}}{\delta_{1}} \times 100 \%
$$

While a study held in JPCP joints indicated a minimum LTE of $75 \%$ as an indication of pavement good structural performance [10], another work showed, again in JPCP joints, that for new pavements without dowel bars, the LTE varied between 70 and $100 \%$, and that for new pavements with dowel bars, the lower limit was upgraded to $80 \%$ [11]. The author considers a LTE lower than $70 \%$ unacceptable. For CRCP, LTE below $70 \%$ is also considered problematic [5].

Since the sensor device configuration was $0,200,300,450$, 600,900 and $1200 \mathrm{~mm}$, and the load plate had a $300 \mathrm{~mm}$ diameter (first sensor), it was decided to use the deflections measured by the sensor at points 0 and 300 , as shown in Figure 2 . The previously stipulated load was $60 \mathrm{kN}$ due to the need of a 
more detailed deflection reading, which a lower load could not provide due to the high stiffness of a concrete pavement with such steel ratios. Also, tests were performed in the middle of the slabs, between consecutive cracks, in order to analyze the deflection basins and to determine essential parameters, through backcalculation, to study slab performance such as the concrete modulus of elasticity $(E)$ and subgrade reaction module $(k)$. As section 1 has no visible cracks yet, the FWD tests at this section were conducted 5 meters from each edge and then with a 10 -meter spacing. Since each stretch has a width of $5.05 \mathrm{~m}$, the test point was always in the middle of the width, i. e., 2.525 $\mathrm{m}$ from the road center axis. Figure 3 encodes each point as a crack $(F)$ or slab $(P)$ in all sections.

\subsection{Backcalculation methodology}

The consistent simulation of the slab structure behavior with a theory by means of strains or stresses of the actual structure is a quite suitable backcalculation concept. For such, the theoretical model (analytical or numerical) must be able to represent the pavement geometric configuration and the loading parameters employed. Once all the necessary elements are provided, the theoretical simulation thus relies on a search through successive approximations, for a theoretical response with sufficient level of representation of the real answer. The most usual method of checking the quality of these approaches is the analysis of the squared error between the theoretically calculated deflections and actual measured deflections in the field. Equation 2 dictates this method.

$$
\text { SquaredError }=\Sigma\left(\delta_{i}^{\text {Field }}-\delta_{i}^{\text {Theoretical }}\right)^{2}
$$

$\mathrm{E}$ and $\mathrm{k}$ are known to range with the pavement age, which may make measured values during construction quality control not representative, for example. To estimate the input values of $k$ and $E$ based on the deflections obtained, studies by Hall [12] and Crovetti [13] are used herein. In the first research, the structural answer analysis of innumerous concrete pavement sections based on the slab radius of relative stiffness $(\ell)$ concept defined the following relation (Equation 3 and Equation 4 ) between this parameter and the field deflections [12].

$$
\ell=\left[\frac{\ln \left(\frac{36-A R E A}{1812.279133}\right)}{-2.55934}\right]^{4.387009}
$$

\section{Figure 3 - FWD crack (F) and slab center (P) points}
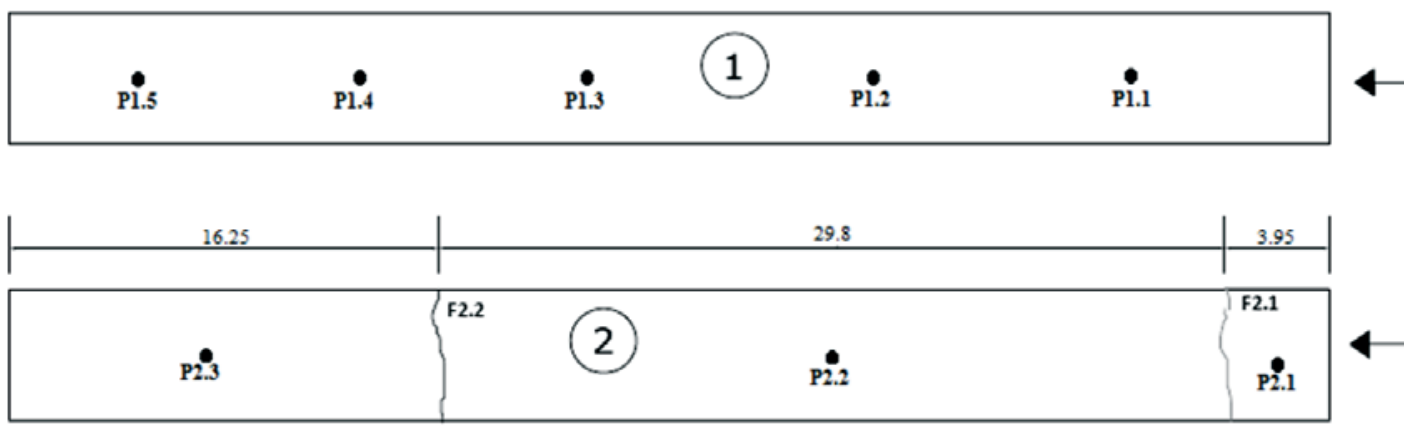

\begin{tabular}{|c|c|c|c|c|c|c|c|}
\hline P4.1 & $\stackrel{\text { F4.1 }}{\bullet}$ & F4.2 & $\int^{F 4.3}$ & F4.4 & F4.5 & 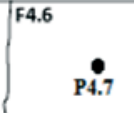 & $\begin{array}{l}\text { F4.7 } \\
\text { P4.8 }\end{array}$ \\
\hline 4.37 & 5.29 & 6.57 & 9.53 & 6.64 & 5.64 & 7.3 & 4.66 \\
\hline
\end{tabular}

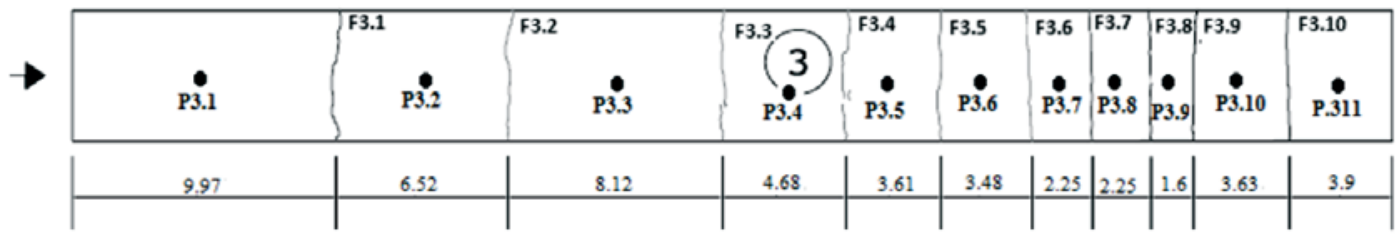




$$
A R E A=6\left(1+\frac{2 \delta_{30}}{\delta_{0}}+\frac{2 \delta_{60}}{\delta_{0}}+\frac{\delta_{90}}{\delta_{0}}\right)
$$

The parameter AREA is the deflection basin area normalized by the maximum deflection in relation to a FWD load applied onto a $300 \mathrm{~mm}$ diameter plate. It is worth highlighting that the concept behind the study is based on loadings in the slab center. The knowledge of $\ell$ allows using the Westergaard equations for the load in the slab center to determine the values of $k$ and $E$ [13]. To this end, Equation 5 and Equation 6 are used.

$$
k=\frac{P}{8 . \delta_{0} \cdot \ell^{2}}\left\{1+\left(\frac{1}{2 \pi}\right) \cdot\left[\ln \left(\frac{a}{2 . \ell}\right)-0.67278436\right] \cdot\left(\frac{a}{\ell}\right)^{2}\right\}
$$

$$
E=\frac{12\left(1-\mu^{2}\right) \cdot k \cdot \ell^{4}}{h^{3}}
$$

\section{Where:}

$\mathrm{P}=\mathrm{FWD}$ loads (lbf)

$\mathrm{a}=\mathrm{FWD}$ plate radius $(\mathrm{pol})$

$\mu=$ Poisson ratio

$\mathrm{h}=$ slab thickness

Note that the model presented has its application field limited to infinite slabs with loads in its center. It should also be noted that for k-values, the calculated numbers refer to a static load; however, the FWD is a dynamic load; thus, the actual values should be higher than the estimated ones. Table 1 shows the estimated values of $k$ and $E$ according to the methodology described above. Note that only slab center FWD points were selected for the analysis. These values will be used as the initial input in the software for the backcalculation process.

\subsubsection{The EverFe software}

First presented in 1998, the EverFe, now in version 2.24, allows numerical simulations of load tests by finite element. Using the software, it is possible to simulate the real tests in order to verify the values of $E$ and $k$.

Although the model was specifically developed for JPCP, it is possible to simulate other concrete slabs structures knowing their geometric configurations. The software can simulate up to three layers (each with its own characteristics and parameters) and transverse and longitudinal joints between slabs; the maximum number of slabs is nine. In addition, the software allows a number of vehicle axle configurations and loads that satisfactorily contemplates the traffic conditions currently found in highways [14].

To simulate the experimental CRCP, firstly, the sections geometric configuration was informed. The cracks were simulated as joints; a slab is considered the space between consecutive cracks (joints); hence, section 3 has eleven slabs, for example. Section 1 was simulated as a single slab with five FWD loading points. For the cracked sections, aiming to provide the continuous pavement configuration, the prior and posterior slabs to the analyzed slab were considered for each $\mathrm{P}$ point.

Some considerations regarding the simulation:

- Along with the concrete slab, it was chosen to simulate only the base layer. When simulating with or without the granular subbase layer, it was observed that the effect on the deflections was negligible;

- The resilience modulus of the asphalt concrete base was based on the analyses of two studies that indicate a relatively high modulus to asphalt layers isolated (between two layers) because it is less exposed to thermal variations than the surface layer [15] [16];

- The values concerning the slab-base friction were set at 10 each, just to not let them null; again, in the simulations it was observed that a three-value variation on a scale of 1 to 100 does not cause significant changes in the deflection;

- Regarding the slab thermal gradients, the temperature during the FWD test was $20^{\circ} \mathrm{C}$ on a very cloudy day. According to the equations developed during a thermal research in São Paulo, the thermal gradient between top and bottom should be of $7^{\circ}[17]$. Applying this value to EverFE, the slab suffers such a severe warping that deflections turned negative; even decreasing this value to $2^{\circ} \mathrm{C}$, the resulting deflections were only matched with the field deflections with an E larger than 200MPa, which is very unlikely in the concrete applied. The software is believed to present some errors concerning the thermal effects. Therefore, the thermal differential used was zero;

- As the longitudinal reinforcement on the CRCP has no load transferring function - its only purpose is to keep the cracks closed -, the cracks (joints) were considered to have no reinforcement [18]. The only crack input was the crack width and the crack stiffness based on the crack width [19].

Based on the estimated $E$ and $k$ shown in Table 1, backcalculation attempts for an approximate value of $E$ and a value twice the estimated $\mathrm{k}$ were initiated. It is known that increasing the value of $\mathrm{k}$ and $\mathrm{E}$ makes the structure stiffer, reducing the deflections. With each attempt, the percentage error and the squared error were analyzed, until the lowest possible error was obtained, this being the most appropriate and representative of the field test basin. It was clearly seen in all the basins matching that $\mathrm{k}$ was more influential in the last three deflection sensors; on the other hand, the E modified deflections of the first three sensors more intensely. After this finding, the process changed to first fix a value of $k$ that corresponds to a very low error for the sensors at 600,900 and $1200 \mathrm{~mm}$, and then the $E$ was ranged until the 0,200 and $300 \mathrm{~mm}$ sensors were adequate. An example of this matching process can be found in Table 2 and in Figure 4. In the case presented, try number P1.4h was the one that best represented the field data.

\section{Results and discussions}

The deflections in the slabs center allowed the deflection basin layout shown in Figure 5. Firstly, we note that the lower maximum deflection occurs at the longer slab formed between cracks, P2.2 in section 2 center. This can be explained by the section higher ratio of reinforcement which gives it greater stiffness. The largest maximum deflections - values above $25 \times 10^{-2} \mathrm{~mm}$ - were always found near the sections transverse edges. The lack of anchorage 
Table 1 - Estimated parameters for slab center FWD loadings

\begin{tabular}{|c|c|c|c|c|c|}
\hline Point & $\begin{array}{l}\text { Load } \\
\text { (Kgf) }\end{array}$ & Area & $\ell($ pol) & $\begin{array}{c}\mathrm{k} \\
\mathrm{MPa} / \mathrm{m}\end{array}$ & $\begin{array}{c}\mathrm{E} \\
\mathrm{MPa}\end{array}$ \\
\hline P4.1 & 6171 & 33.344 & 60.710 & 10.022 & 48,080 \\
\hline P4.2 & 6198 & 32.238 & 47.733 & 20.106 & 36,862 \\
\hline P4.3 & 6227 & 31.985 & 45.561 & 42.883 & 65,265 \\
\hline P4.4 & 6200 & 31.473 & 41.769 & 29.349 & 31,552 \\
\hline P4.5 & 6187 & 32.670 & 52.005 & 20.460 & 52,858 \\
\hline P4.6 & 6219 & 29.758 & 32.801 & 70.594 & 28,861 \\
\hline P4.7 & 6169 & 31.362 & 41.032 & 41.544 & 41,591 \\
\hline P4.8 & 6167 & 31.729 & 43.576 & 34.023 & 43,328 \\
\hline P3.1 & 6192 & 30.981 & 38.702 & 36.600 & 29,003 \\
\hline P3.2 & 6170 & 30.670 & 36.999 & 38.493 & 25,477 \\
\hline P3.3 & 6214 & 32.792 & 53.378 & 25.667 & 73,588 \\
\hline P3.4 & 6169 & 31.608 & 42.701 & 40.960 & 48,094 \\
\hline P3.5 & 6206 & 31.283 & 40.524 & 48.133 & 45,844 \\
\hline P3.6 & 6159 & 31.248 & 40.307 & 46.972 & 43,789 \\
\hline P3.7 & 6169 & 31.834 & 44.372 & 37.039 & 50,713 \\
\hline P3.8 & 6170 & 31.906 & 44.930 & 33.390 & 48,057 \\
\hline P3.9 & 6159 & 32.173 & 47.158 & 26.303 & 45,943 \\
\hline P3.10 & 6163 & 31.811 & 44.192 & 26.378 & 35,531 \\
\hline P3.11 & 6134 & 31.732 & 43.596 & 20.082 & 25,622 \\
\hline P1.1 & 6100 & 31.646 & 42.976 & 16.147 & 19,453 \\
\hline P1.2 & 6177 & 31.979 & 45.513 & 29.476 & 44,671 \\
\hline P1.3 & 6198 & 31,704 & 43.391 & 37.671 & 47,164 \\
\hline P1.4 & 6181 & 30.541 & 36.341 & 64.536 & 39,753 \\
\hline P1.5 & 6130 & 31.896 & 44.852 & 22.634 & 32,351 \\
\hline P2.1 & 6167 & 33.680 & 66.428 & 11.704 & 80,488 \\
\hline P2.2 & 6190 & 30.297 & 35.153 & 90.736 & 48,938 \\
\hline P2.3 & 6146 & 31.551 & 42.299 & 35.726 & 40,393 \\
\hline
\end{tabular}

at these points elucidates this fact; near the edge, the slab is freer to move and it is not uncommon to feel a vertical displacement when a heavy vehicle access or exit the stretch. Despite its increased reinforcement ratio in relation to sections 3 and 4 , section 1 presents point (P1.1) with the largest maximum deflection $\left(38 \times 10^{-2} \mathrm{~mm}\right)$ - much larger as compared to the second largest, the P4.1 point (section 4) with $31,4 \times 10^{-2} \mathrm{~mm}$; this happens because there is a settlement flaw in the interlocked pavement near the joint with the experimental CRCP. This failure caused faulting and breaking in the slab corner as shown in Figure 6. At this point, the vertical "bump" is more easily noticed. It is also interesting to note that the two points with the largest displacements are those where the vehicles access the experimental $\mathrm{CRCP}$, which suggest a more advanced concrete deterioration due to the vertical impact at these points. As for the shape, except for the P1.1 basin, all the basins seem a typical outline for rigid pavements with a smooth deflection decrease through sensors.

Deflections at the crack also enabled the deflection basins layout as seen in Figure 7 . The graph analysis shows the non-occurrence of very high maximum deflections, as expected; cracks are fur- ther from the edge than the final and initial slabs, which makes the displacements due to lack of anchorage less influential. Despite the lower values, the two highest maximum deflections are, again, close to the edge (F3.10 and F4.1). No significant increase in deflections was noticed when comparing the measures taken at the crack and in the slabs center - in some cases, the crack deflections were even smaller. A study showed in a JPCP that joints without dowel bars presented much higher deflections than joints with dowel bars [20]. Even though the CRCP joints (cracks) do not have dowel bars, the cracks small width added to the tightening strength provided by the longitudinal reinforcement, which increases the stiffness, decrease deflections even in a physical discontinuity.

\subsection{Load transfer efficiency across cracks}

The FWD loading tangential to the crack provided equidistant deflections; the use of Equation 1 allowed the LTE calculation. Figure 8 illustrates the LTE value for each crack. Figure 8 allows the following findings:

- All cracks showed LTE over 90\% (average 92.7\%); 


\section{Table 2 - Deflections matching process for point P1.4}

\begin{tabular}{|c|c|c|c|c|c|c|c|c|c|c|c|c|}
\hline \multirow[b]{2}{*}{ Try } & \multicolumn{3}{|c|}{ Deflections (0.01 mm) } & \multirow{2}{*}{$\begin{array}{c}0 \\
13.3\end{array}$} & \multirow{2}{*}{$\begin{array}{l}200 \\
12.5\end{array}$} & \multirow{2}{*}{$\begin{array}{r}300 \\
12.0\end{array}$} & \multirow{2}{*}{$\begin{array}{l}450 \\
11.3\end{array}$} & \multirow{2}{*}{$\begin{array}{c}600 \\
10.6\end{array}$} & \multirow{2}{*}{$\begin{array}{l}900 \\
9.2\end{array}$} & \multirow{2}{*}{$\begin{array}{l}1200 \\
8.1\end{array}$} & \multirow{2}{*}{$\begin{array}{c}\text { Error } \\
(\%) \\
\text { Total }\end{array}$} & \multirow[b]{2}{*}{ Error $^{2}$} \\
\hline & File & $\mathrm{E}(\mathrm{MPa})$ & $\begin{array}{c}\mathrm{k} \\
(\mathrm{MPa} / \mathrm{m})\end{array}$ & & & & & & & & & \\
\hline 1 & pl.4a & 35,000 & $\begin{array}{c}120 \\
\text { Error(\%) }\end{array}$ & $\begin{array}{c}15.5 \\
16.5 \%\end{array}$ & $\begin{array}{c}15.7 \\
25.6 \%\end{array}$ & $\begin{array}{c}15.1 \\
25.8 \%\end{array}$ & $\begin{array}{c}14.3 \\
26.5 \%\end{array}$ & $\begin{array}{c}13.4 \\
26.4 \%\end{array}$ & $\begin{array}{c}11.8 \\
28.3 \%\end{array}$ & $\begin{array}{c}10.6 \\
30.9 \%\end{array}$ & $180.06 \%$ & 54.54 \\
\hline 2 & $\mathrm{pl} .4 \mathrm{~b}$ & 35,000 & $\begin{array}{c}130 \\
\text { Error(\%) }\end{array}$ & $\begin{array}{c}14.7 \\
10.5 \%\end{array}$ & $\begin{array}{c}14.8 \\
18.4 \%\end{array}$ & $\begin{array}{c}14.3 \\
19.2 \%\end{array}$ & $\begin{array}{c}13.4 \\
18.6 \%\end{array}$ & $\begin{array}{c}12.6 \\
18.9 \%\end{array}$ & $\begin{array}{c}11.0 \\
19.6 \%\end{array}$ & $\begin{array}{c}9.8 \\
21.0 \%\end{array}$ & $126.10 \%$ & 27.08 \\
\hline 3 & $\mathrm{pl} .4 \mathrm{c}$ & 38,000 & $\begin{array}{c}\text { Error(\%) } \\
130\end{array}$ & $\begin{array}{c}10.5 \% \\
14.4\end{array}$ & $\begin{array}{c}18.4 \% \\
14.5\end{array}$ & $\begin{array}{c}19.2 \% \\
14.0\end{array}$ & $\begin{array}{c}18.6 \% \\
13.2\end{array}$ & $\begin{array}{c}12.4 \\
17.0 \%\end{array}$ & $\begin{array}{c}10.9 \\
18.5 \%\end{array}$ & $\begin{array}{c}9.8 \\
21.0 \%\end{array}$ & $114.20 \%$ & 21.84 \\
\hline 4 & $\mathrm{pl} .4 \mathrm{~d}$ & 38,000 & $\begin{array}{c}140 \\
\text { Error(\%) }\end{array}$ & $\begin{array}{l}13.6 \\
2.3 \%\end{array}$ & $\begin{array}{c}13.8 \\
10.4 \%\end{array}$ & $\begin{array}{l}13.1 \\
9.2 \%\end{array}$ & $\begin{array}{c}12.5 \\
10.6 \%\end{array}$ & $\begin{array}{c}11.7 \\
10.4 \%\end{array}$ & $\begin{array}{c}10.2 \\
10.9 \%\end{array}$ & $\begin{array}{c}9.1 \\
12.3 \%\end{array}$ & $66.03 \%$ & 7.64 \\
\hline 5 & $\mathrm{pl} .4 \mathrm{e}$ & 38,000 & $\begin{array}{c}145 \\
\text { Error(\%) }\end{array}$ & $\begin{array}{l}13.3 \\
0.0 \%\end{array}$ & $\begin{array}{l}13.4 \\
7.2 \%\end{array}$ & $\begin{array}{l}12.9 \\
7.5 \%\end{array}$ & $\begin{array}{l}12.2 \\
8.0 \%\end{array}$ & $\begin{array}{l}11.4 \\
7.5 \%\end{array}$ & $\begin{array}{c}9.9 \\
7.6 \%\end{array}$ & $\begin{array}{c}8.9 \\
9.9 \%\end{array}$ & $47.70 \%$ & 4.20 \\
\hline 6 & $\mathrm{pl} 1.4 \mathrm{f}$ & 38,000 & $\begin{array}{c}150 \\
\text { Error(\%) }\end{array}$ & $\begin{array}{l}13.0 \\
2.3 \%\end{array}$ & $\begin{array}{l}13.1 \\
4.8 \%\end{array}$ & $\begin{array}{l}12.6 \\
5.0 \%\end{array}$ & $\begin{array}{l}11.9 \\
5.3 \%\end{array}$ & $\begin{array}{l}11.1 \\
4.7 \%\end{array}$ & $\begin{array}{c}9.6 \\
4.3 \%\end{array}$ & $\begin{array}{c}8.6 \\
6.2 \%\end{array}$ & $32.60 \%$ & 1.83 \\
\hline 7 & $\mathrm{pl} .4 \mathrm{~g}$ & 40,000 & $\begin{array}{c}150 \\
\text { Error(\%) }\end{array}$ & $\begin{array}{l}12.8 \\
3.8 \%\end{array}$ & $\begin{array}{l}13.0 \\
4.0 \%\end{array}$ & $\begin{array}{l}12.5 \\
4.2 \%\end{array}$ & $\begin{array}{l}11.7 \\
3.5 \%\end{array}$ & $\begin{array}{l}11.0 \\
3.8 \%\end{array}$ & $\begin{array}{c}9.6 \\
4.3 \%\end{array}$ & $\begin{array}{c}8.6 \\
6.2 \%\end{array}$ & $29.76 \%$ & 1.48 \\
\hline 8 & $\mathrm{pl} .4 \mathrm{~h}$ & 38,000 & $\begin{array}{c}160 \\
\text { Error(\%) }\end{array}$ & $\begin{array}{l}12.7 \\
4.5 \%\end{array}$ & $\begin{array}{l}12.6 \\
0.8 \%\end{array}$ & $\begin{array}{l}12.1 \\
0.8 \%\end{array}$ & $\begin{array}{l}11.3 \\
0.0 \%\end{array}$ & $\begin{array}{l}10.6 \\
0.0 \%\end{array}$ & $\begin{array}{c}9.1 \\
1.1 \%\end{array}$ & $\begin{array}{c}8.1 \\
0.0 \%\end{array}$ & $7.23 \%$ & 0.39 \\
\hline 9 & $\mathrm{pl} .4 \mathrm{i}$ & 40,000 & $\begin{array}{c}155 \\
\text { Error(\%) }\end{array}$ & $\begin{array}{l}12.8 \\
3.8 \%\end{array}$ & $\begin{array}{l}12.9 \\
3.2 \%\end{array}$ & $\begin{array}{l}12.4 \\
3.3 \%\end{array}$ & $\begin{array}{l}11.6 \\
2.7 \%\end{array}$ & $\begin{array}{l}10.9 \\
2.8 \%\end{array}$ & $\begin{array}{c}9.4 \\
2.2 \%\end{array}$ & $\begin{array}{c}8.3 \\
2.5 \%\end{array}$ & $20.42 \%$ & 0.83 \\
\hline 10 & pl.4j & 40,000 & $\begin{array}{c}160 \\
\text { Error(\%) }\end{array}$ & $\begin{array}{l}12.2 \\
8.3 \%\end{array}$ & $\begin{array}{l}12.4 \\
0.8 \%\end{array}$ & $\begin{array}{l}11.9 \\
0.8 \%\end{array}$ & $\begin{array}{l}11.2 \\
0.9 \%\end{array}$ & $\begin{array}{l}10.5 \\
0.9 \%\end{array}$ & $\begin{array}{c}9.1 \\
1.1 \%\end{array}$ & $\begin{array}{c}8.1 \\
0.0 \%\end{array}$ & $12.82 \%$ & 1.26 \\
\hline
\end{tabular}

The crack with the lowest LTE $(90.52 \%)$ is F3.1, positioned at the end of section 3; however, strangely, the crack with the highest LTE (95.51\%) also lies on a section edge - section 4 in that case. Deflections were quite large in this position as seen in Figures 5 and 7; however, more or less displacement does not seem to influence the crack load transferring potential.

- As some researchers stress, the crack spacing influence was not observed in the LTE. Figure 9 shows the relationship between the LTE and the crack spacing of loaded and unloaded crack. No trend is verified, i.e., very large crack spacing as those presented by section 2 are not harmful to the load transfer;

- Another aspect is that when simulating a crack at the $P$ points (slabs center) and calculating the LTE for this fictitious crack, the values are very similar to those of Figure 8; this means that

Figure 4 - Deflection basin matching for P1.4

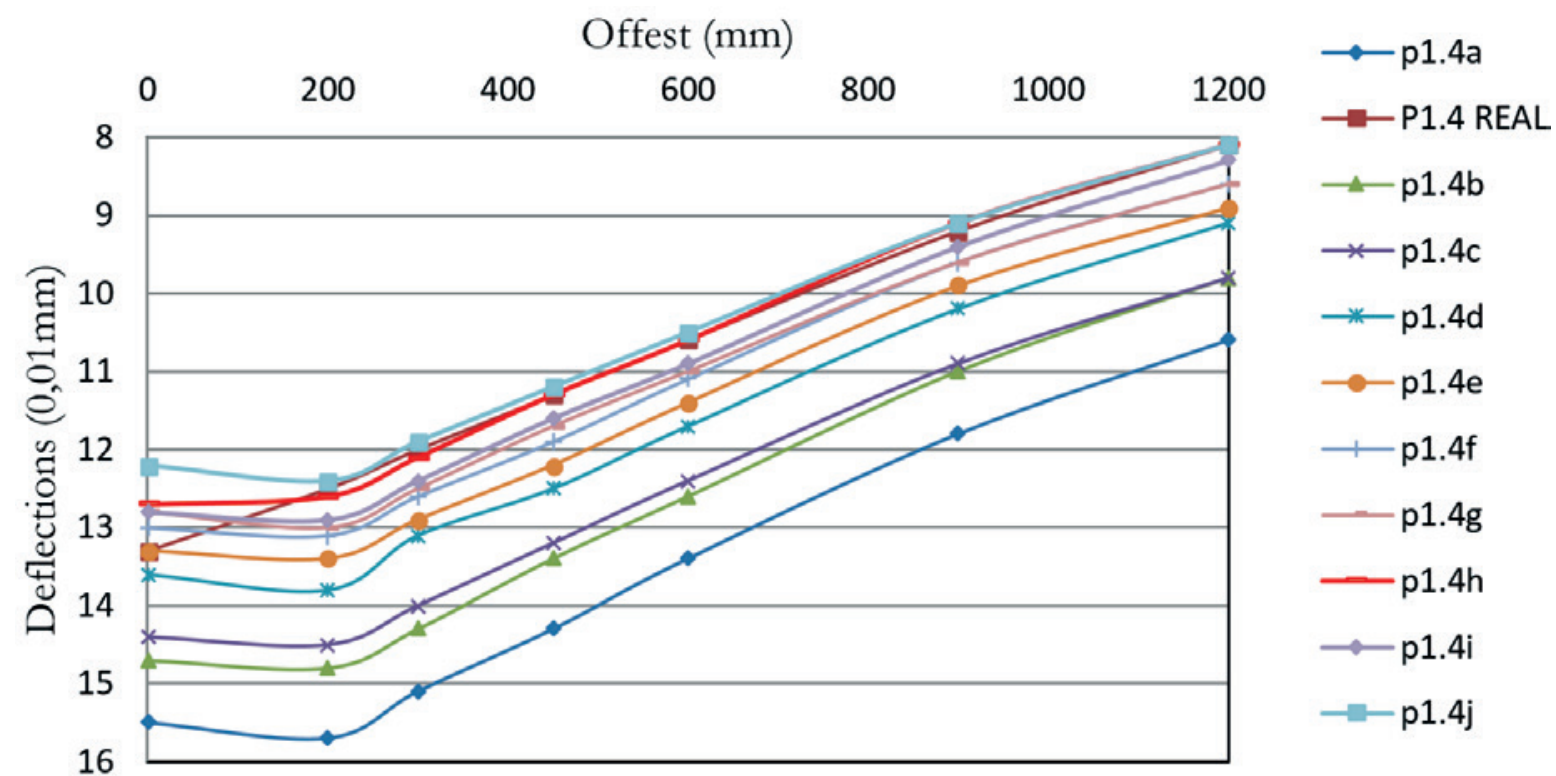


regarding load transfer, the short $\mathrm{CRCP}$ cracking behaves as a continuous structure. The simulated LTE data are shown in Table 3

\subsection{Backcalculation analysis}

Before any analysis, it should be clear that, although the concrete used was the same for all sections, provided by the same supplier, the construction happened in different days for each section and it is know that concrete, a heterogeneous material, can present different properties even in a small volume. In addition, constructive problems such as exudation and segregation of fresh concrete may happen. All these variables are aggravated by the pouring and vibration of the material, which is certainly not homogeneous in situ. These factors are influential on the FWD test results, which may consequently affect the basin matching during the backcalcutation. With these presuppositions in mind, the $\mathrm{E}$ and $\mathrm{k}$ results are presented for all $P$ points in table 4 .

In spite of the factors discussed above, of the 27 basins analyzed, only three cases (P3.3, P2.1 and P1.1) could not find a satisfactory theoretical basin match according to the criteria presented. This validates the FWD testing. An extra explanation for these three cases could be that during the FWD test, the loading plate was not uniformly placed on the surface due to the presence of very hard aggregates, which can lead to uneven pressures. This is very likely to have occurred in P3.3. However, for the P2.1 and P1.1 slabs, because of its location in the sections longitudinal edge, the software used may be assumed not to have perfectly simulated the slab anchorage system - or lack of it.

By analyzing the values of $k$ and $E$, it appears that, except for the P4.4 and P4.6, the nearest from the edge, the lowest values for both parameters are presented; and more, especially at the slabs edge where vehicles access the sections, the minimum values were found. This fact is easily explained by the absence of an anchoring system, which means that there is greater displacement at the edges and also due to this displacement, a larger deterioration of the concrete and the structure as a whole at these points.

Excluding these minimum values influenced by the edge, there is

\section{Figure 5 - Deflection basins for slab center loadings}

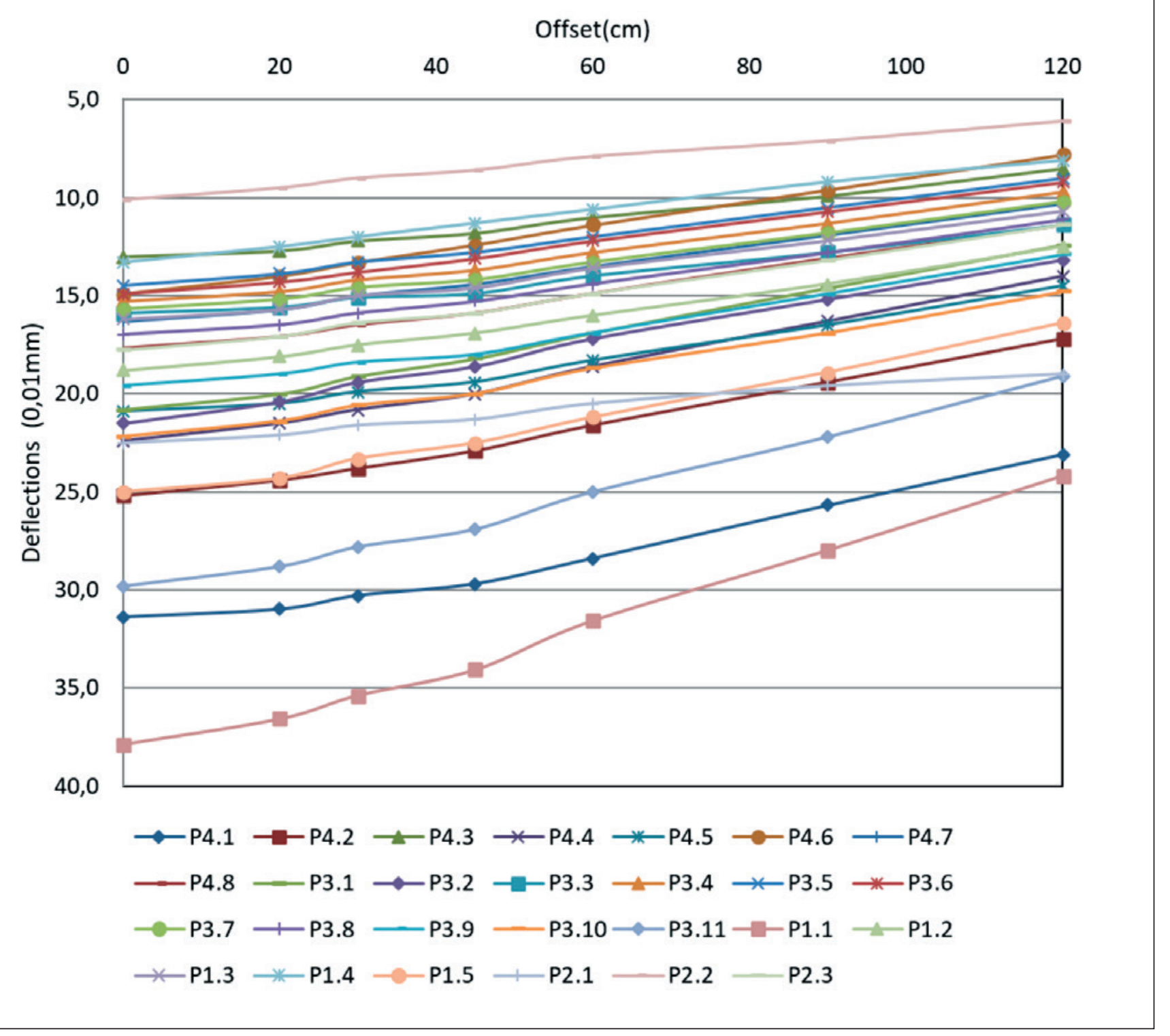




\section{Figure 6 - Concrete deterioration at the transversal edge}

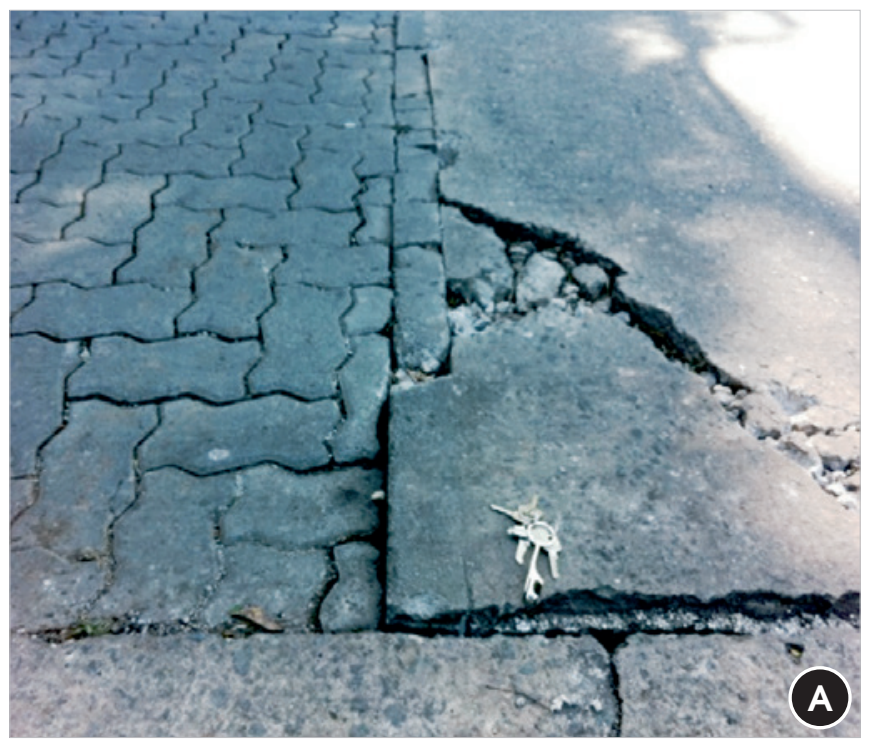

an $\mathrm{E}$ variation from 34,000 to $38,000 \mathrm{MPa}$ for section $1 ; 25,000$ to $42,000 \mathrm{MPa}$ for section 3; and 25,000 to $45,000 \mathrm{MPa}$ for section 4. This variation is common and expected in large volumes of concrete as a pavement slab. When checking the smallest squared

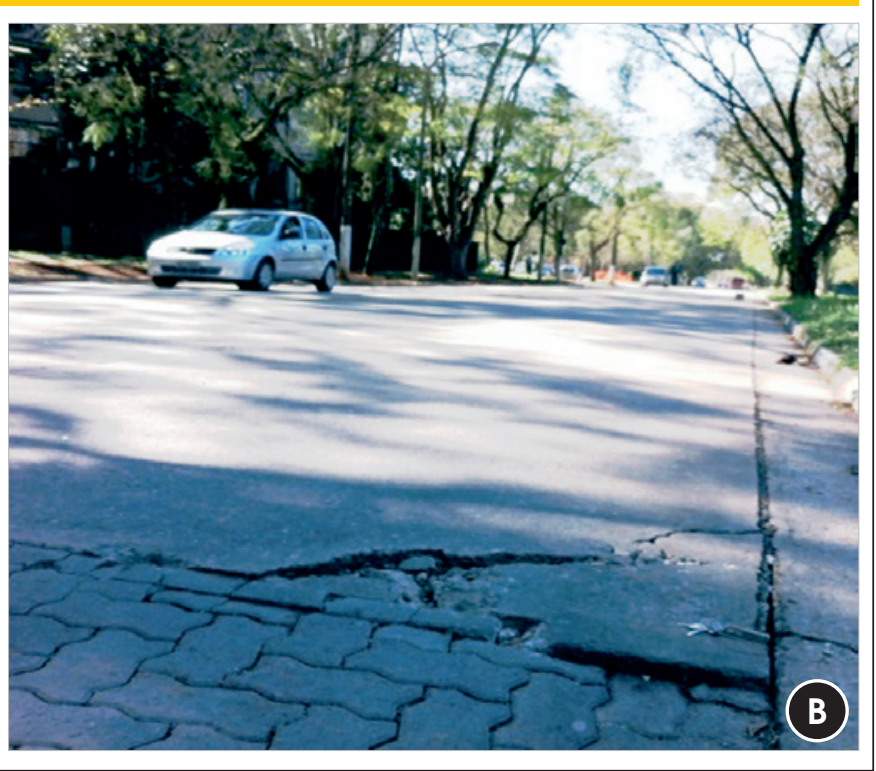

error, the most representative values for each section are 38,000 $\mathrm{MPa}$ for section 1; 35,000 MPa for section 2; 38,000 MPa for section 3; and 25,000 MPa for section 4. For section 2, as there are only three $\mathrm{P}$ points, the most representative ended up being the

Figure 7 - Deflection basins at crack

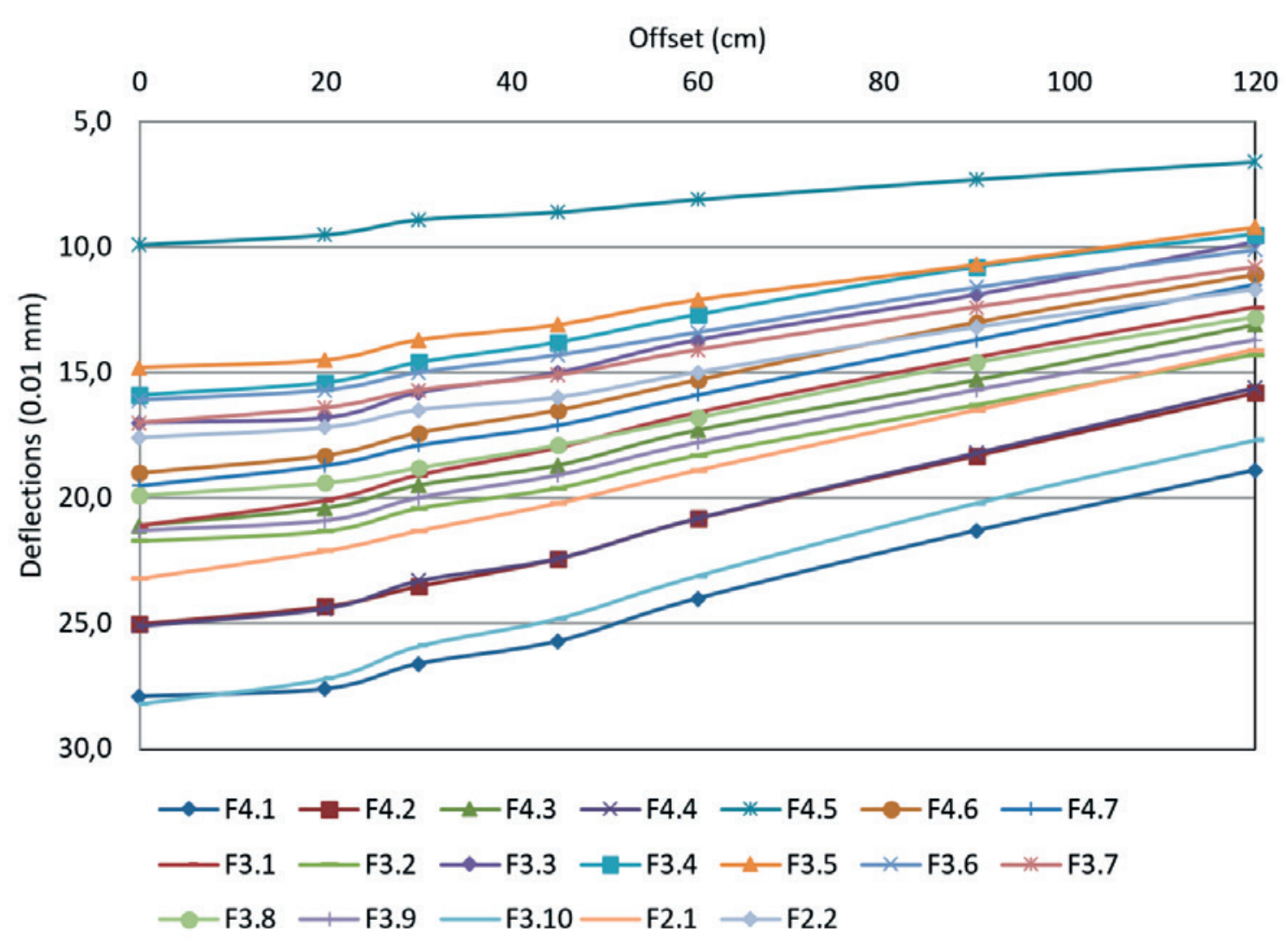




\section{Figure 8 - LTE for each crack}

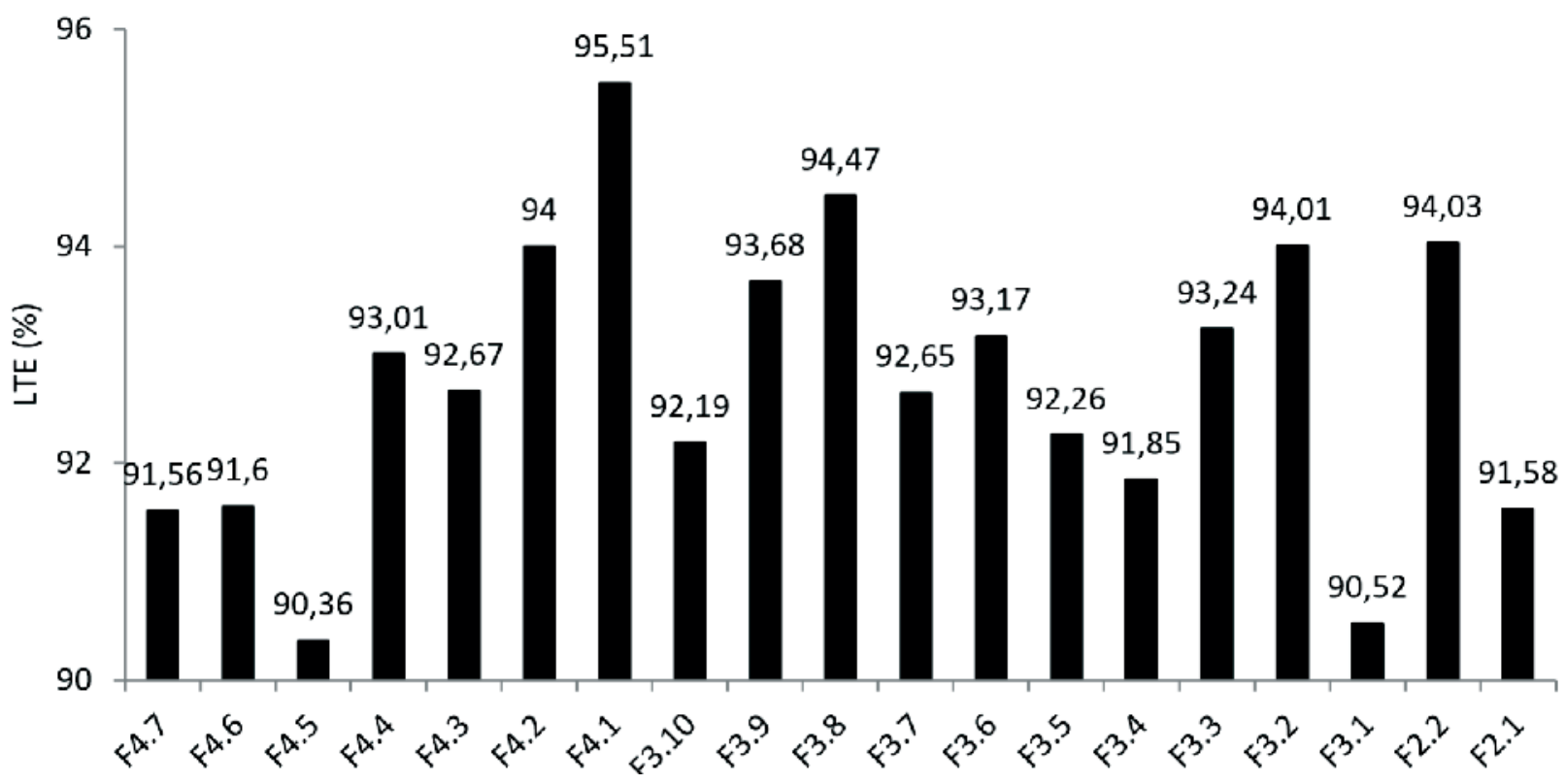

closest to the edge; furthermore, the value of $60,000 \mathrm{MPa}$ (near the slab center) is very high for the concrete used. An FWD testing error could also have occurred in this case, which generated lower deflections. However, it is not entirely wrong to suppose that section 2 presents a more rigid structure due to the large amount of reinforcement steel, since even the edge $P$ points resulted in $E$ in the magnitude of $30,000 \mathrm{MPa}$.

Concerning $\mathrm{k}$, the parameter variation, excluding the values near the edge, resulted in 95 to $160 \mathrm{MPa} / \mathrm{m}$ (Section 1); 85 to $135 \mathrm{MPa} / \mathrm{m}$ (Section 3); 70 to $155 \mathrm{MPa} / \mathrm{m}$ (Section 4). loannides [21] states that the modulus of subgrade reaction is not an intrinsic property of the soil, but a representation of the structure support as a whole. Thus, it is perfectly normal for a complex structure with several layers of different materials to present the variations mentioned. Values denote a fairly stiff base on the subgrade; a research found for a JPCP with a lean concrete base, in an area close to the short CRCP, values between 60 and $125 \mathrm{MPa} / \mathrm{m}$ [20]. The sections are better represented (lower square error) for $\mathrm{k}$ equal to $160 \mathrm{MPa} / \mathrm{m}$ (Section 1); 105 $\mathrm{MPa} / \mathrm{m}$ (Section 2); $135 \mathrm{MPa} / \mathrm{m}$ (Section 3); and $85 \mathrm{MPa} / \mathrm{m}$ (Section 4). Again, section 2, even near the edge, presents high values.

Figure 9 - Crack spacing versus LTE

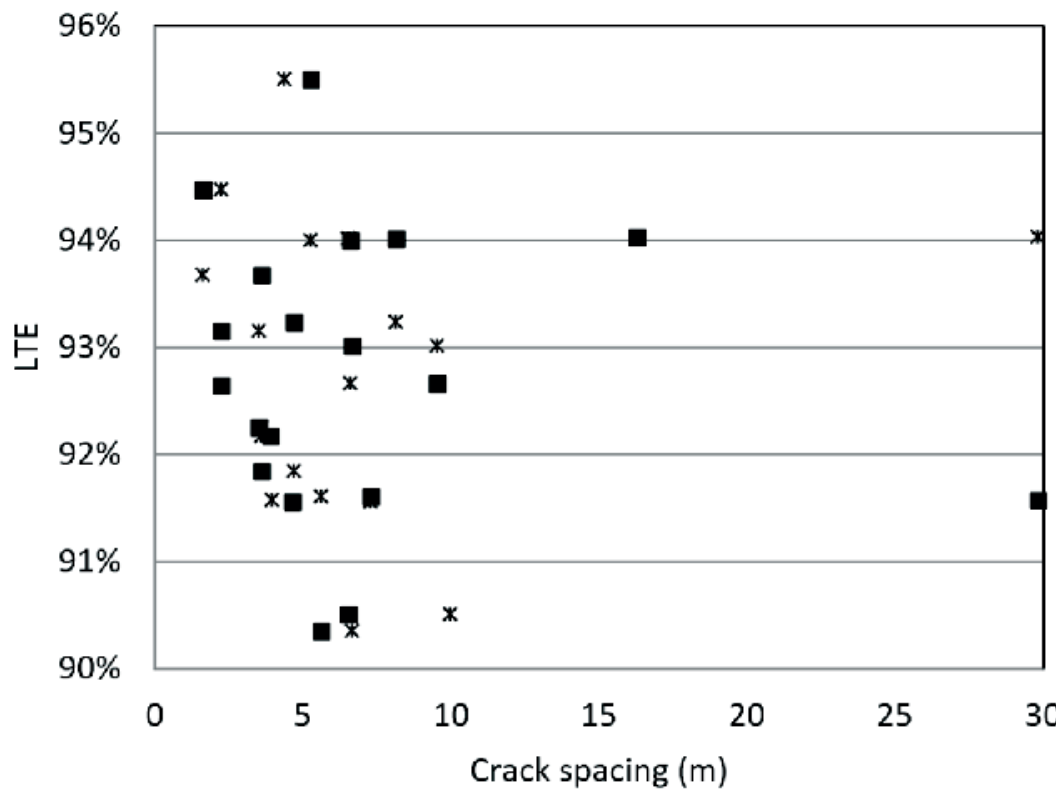

* Loaded slab

- Unloaded slab 


\section{Table 3 - Fictitious LTE in the slab center}

\begin{tabular}{|cccc|}
\hline Point & \multicolumn{2}{c}{ Deflections $(\mathbf{0 . 0 1} \mathbf{~ m m})$} & LTE \\
\hline P4.1 & 0 & 300 & $96.50 \%$ \\
\hline P4.2 & 31.4 & 30.3 & $94.44 \%$ \\
\hline P4.3 & 25.2 & 23.8 & $93.85 \%$ \\
\hline P4.4 & 13.0 & 12.2 & $92.86 \%$ \\
\hline P4.5 & 22.4 & 20.8 & $95.22 \%$ \\
\hline P4.6 & 20.9 & 19.9 & $89.26 \%$ \\
\hline P4.7 & 14.9 & 13.3 & $92.02 \%$ \\
\hline P4.8 & 16.3 & 15.0 & $93.22 \%$ \\
\hline P3.1 & 20.8 & 16.5 & $91.83 \%$ \\
\hline P3.2 & 21.5 & 19.1 & $90.23 \%$ \\
\hline P3.3 & 15.9 & 19.4 & $94.97 \%$ \\
\hline P3.4 & 15.3 & 15.1 & $92.81 \%$ \\
\hline P3.5 & 14.5 & 14.2 & $91.72 \%$ \\
\hline P3.6 & 14.9 & 13.3 & $92.62 \%$ \\
\hline
\end{tabular}

\begin{tabular}{|c|c|c|c|}
\hline \multirow{2}{*}{ Point } & \multicolumn{2}{|c|}{ Deflections $(0.01 \mathrm{~mm})$} & \multirow{2}{*}{ LTE } \\
\hline & 0 & 300 & \\
\hline P3.7 & 15.7 & 14.6 & $92.99 \%$ \\
\hline P3.8 & 17.0 & 15.9 & $93.53 \%$ \\
\hline P3.9 & 19.6 & 18.4 & $93.88 \%$ \\
\hline P3.10 & 22.2 & 20.6 & $92.79 \%$ \\
\hline P3.11 & 29.8 & 27.8 & $93.29 \%$ \\
\hline $\mathrm{Pl} .1$ & 37.9 & 35.4 & $93.40 \%$ \\
\hline $\mathrm{Pl} .2$ & 18.8 & 17.5 & $93.09 \%$ \\
\hline $\mathrm{Pl} .3$ & 16.2 & 15.0 & $92.59 \%$ \\
\hline $\mathrm{Pl} .4$ & 13.3 & 12.0 & $90.23 \%$ \\
\hline $\mathrm{P} 1.5$ & 25.0 & 23.3 & $93.20 \%$ \\
\hline P2.1 & 22.5 & 21.6 & $96.00 \%$ \\
\hline $\mathrm{P} 2.2$ & 10.1 & 9.0 & $89.11 \%$ \\
\hline P2.3 & 17.8 & 16.4 & $92.13 \%$ \\
\hline
\end{tabular}

\section{Conclusions}

By analyzing the deflection basin in the slab center points, the larger deflection was observed to occur near the pavement longitudinal edge. As the sections do not have an anchoring system, the slab has free edges which cause a greater vertical displacement when the slab is loaded. The basins obtained tangential to the cracks showed similar results to those of slab center; again the largest deflections were near the edges. This proves that even without dowel bars at the cracks (joints) the CRCP behaves as a continuous structure. The LTE across cracks showed a very satisfactory performance of the sections. All the cracks presented a value higher than $90 \%$, including those near points that had large deflections. No influence of the reinforcement ratio and the cracks spacing in LTE were visible. By simulating a crack in the slab center points, the fictitious LTE was verified to be very similar to the actual LTE at cracks. This shows that albeit cracked, the pavement behaves as a single structure. The backcalculation process, despite the many simplifications adopted, resulted in a variation of the $E$ and $k$ parameters compatible for most basins. It is clear that, due to the lack of an anchorage system, the deflections in the longitudinal edges of the sections were very large and, consequently, $\mathrm{E}$ and $\mathrm{K}$ were lower at these points. Section 2 presents greater $\mathrm{k}$ and $E$ even for points closer to the edge in a direct influence of the steel amount in the slab stiffness. For Section 1 edge, a settlement presented by interlocked pavement near the experimental CRCP, resulted in fast concrete deterioration, which was proved by the very low $\mathrm{E}$ backcalculated.

\section{Table 4 - Backcalculated E and k}

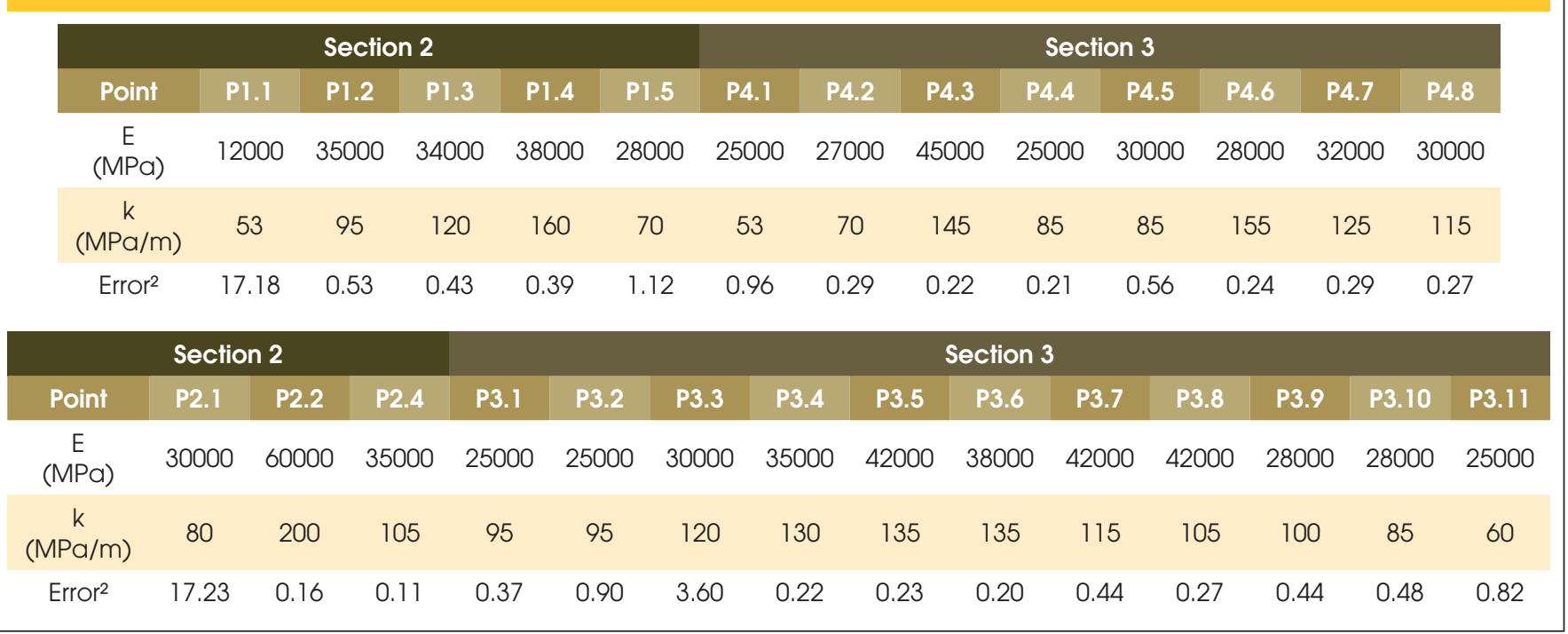




\section{Acknowledgements}

The authors are very grateful to the State of São Paulo Research Foundation (FAPESP) for their support to the research developed at the University of São Paulo aiming to develop designs and construction techniques for concrete pavements in the country, through process \#98/11629-5 and CAPES - Ministry of Education - for the scholarship provided to the first author.

\section{References}

[1] BAYRAK, M. B.; CEYLAN, H. Neural network-based approach for analysis of rigid pavement systems using deflection data. Transportation Research Record: Journal of the Transportation Research Boar, Nº 2068, 2008.

[2] KUTAY, M. E.; CHATTI, K.; LEI, L. Backcalculation of dynamic modulus mastercurve from falling weight deflectometer surface deflections. Transportation Research Record: Journal of the Transportation Research Boar, № 2227, 2011.

[3] SETIADJI, B. H.; FWA, T. F. Consideration of finite slab size in backcalculation analysis of jointed concrete pavements. Transportation Research Record: Journal of the Transportation Research Boar, Nº 2005, 2007.

[4] KHAZANOVICH, L.; GOTILF, A. Evaluation of joint and crack load transfer final report. Federal Highway Administration, FHWA-RD-02-088, Washington D.C., 2003.

[5] ZOLLINGER, D. G.; BARENBERG, E. J. Field investigation of punchout distress in continuously reinforced concrete pavements in Illinois. Transportation Research Record: Journal of the Transportation Research Board, № 1286, 1990a.

[6] KOHLER, E.; ROESLER, J. Active crack control for continuously reinforced concrete pavements. Transportation Research Record: Journal of the Transportation Research Boar, № 1900, 2004.

[7] SALLES, L. S.; BALBO, J. T.; PEREIRA, D. Crack pattern characterization in a short experimental continuously reinforced concrete pavement. 2013 International Journal of Pavements Conference, São Paulo, 2013.

[8] SALLES, L. S.; BALBO, J. T.; PEREIRA, D. Experimental stresses analysis with different load speeds in a short continuously reinforced concrete pavement. Proceedings of the $8^{\text {th }}$ International DUT-Workshop on Research and Innovations for Design of Sustainable and Durable Concrete Pavements, Prague, 2014.

[9] BALBO, J. T.; MASSOLA, A.; PEREIRA, D.; SALLES, L. S. (In portuguese) Aspectos estruturais de um PCCA de extensão reduzida em São Paulo. Anais do $54^{\circ}$ Congresso Brasileiro do Concreto, Maceió, 2012.

[10] SHAHIN, M. Y. Use of the falling weight deflectometer for the non-destructive deflection testing of jointed concrete airfield pavements. 3rd International Conference on Concrete Pavement Design and Rehabilitation, Purdue University, 1985.

[11] VANDENBOSSCHE, J. M. Effects of slab temperature profiles on the use of falling weight deflectometer data to monitor joint performance and detect voids. Transportation Research Board Annual Meeting, Washington D. C., 2007.

[12] HALL, K. T. Performance, evaluation and rehabilitation of asphalt-overlaid concrete pavements. Ph.D. Thesis. University of Illinois, 1991.
[13] CROVETTI, J. A. Design and evaluation of jointed concrete pavement systems incorporating open-graded permeable bases. Ph. D. Dissertation, University of Illinois, 1994.

[14] DAVIDS, W. EverFE: Software for the 3D Finite Element Analysis of Jointed Plain Concrete Pavements. Disponível em at http://www.civil.umaine.edu/everfe, 2004.

[15] SVADISANT, T.; SCHORSCH, M.; BALADI, G. Y.; PINYOSUNUN, S. N. Mechanistic analysis of top-down cracks in asphalt pavements. Transportation Research Record: Journal of the Transportation Research Board, № 1809, 2002.

[16] KIM, W.; LABUZ, J. F.; DAI, S. Resilient modulus of base course containing recycled asphalt pavement. Transportation Research Record: Journal of the Transportation Research Board, N. 2005, 2007.

[17] BALBO, J. T.; SEVERI, A. A. Thermal gradients in concrete pavements in tropical environment. Experimental appraisal. Transportation Research Record: Journal of the Transportation Research Board, №. 1809, 2002.

[18] ZOLLINGER, D. G.; BARENBERG, E. J. Mechanistic design considerations for punchout distress in continuously reinforced concrete pavement. Transportation Research Record: Journal of the Transportation Research Board, No. 1286, 1990b. [2] TAYLOR. H. F. W. Cement Chemistry. London: Thomas Telford. 2ed. 1997. 459 p.

[19] JEONG, J. H.; ZOLLINGER, D. G. Characterization of stiffness parameters in design of continuously reinforced and jointed pavements. Transportation Research Record: Journal of the Transportation Research Boar, No 1778, 2001.

[20] COLIM, G. M.; BALBO J. T.; KHAZANOVICH, L. Effects of temperature changes on load transfer in plain concrete pavement joints. Ibracon Structures and Materials Journal, Vol. 4, N 3, 2011.

[21] IOANNIDES, A.M. CEE 607 - Pavement design: supplementary class notes. University of Cincinnati, 1999. 